Relations industrielles

Industrial Relations

\title{
Loi de la convention collective
}

\section{Marcel Forget}

Volume 2, numéro 9, mai 1947

URI : https://id.erudit.org/iderudit/1023879ar

DOI : https://doi.org/10.7202/1023879ar

Aller au sommaire du numéro

Éditeur(s)

Département des relations industrielles de l'Université Laval

ISSN

0034-379X (imprimé)

1703-8138 (numérique)

Découvrir la revue

Citer cet article

Forget, M. (1947). Loi de la convention collective. Relations industrielles /

Industrial Relations, 2(9), 3-3. https://doi.org/10.7202/1023879ar

Tous droits réservés @ C Département des relations industrielles de l’Université Laval, 1947
Ce document est protégé par la loi sur le droit d'auteur. L'utilisation des services d'Érudit (y compris la reproduction) est assujettie à sa politique d'utilisation que vous pouvez consulter en ligne.

https://apropos.erudit.org/fr/usagers/politique-dutilisation/ 


\section{LOI DE LA CONVENTION COLLECTIVE}

VI.-Dispositions de la convention collective qui sont l'objet du decret:

1.-Dispositions essentielles:

Les dispositions de la convention collective, qu'elles aient été modifiées ou non par le lieutenant-gouverneur en conseil, qui deviennent obligatoires par le fait $\mathrm{d}$ ə l'extension juridique et qui partant lient aussi bien les parties non-contractantes que les parties contractantes, sont les dispositions ncrmatives qui se rapportent:

a) au salaire,

b) à la durée du travail,

c) aux congés payés,

d) à l'apprentissage et

e) au rapport entre le nombre des ouvriers qualifiés et celui des apprentis dans une entreprise donnée (art. 9).

2.-Dispositions accessoires:

Le lieutenant-gouverneur en conseil peut aussi rendre obligatoires, avec ou sans modification, les dispositions de la convention collective qui ont trait:

a) aux allocations familiales,

b) à la classification des opérations,

c) à la détermination des différentes catégories de salariés et d'employeurs,

d) ainsi que celles qu'il estime conformes à l'esprit de la présente loi (art. 10).

N. B.-A remarquer qu'il n'est pas question de fixer dans le décret les prix à être chargés au public pour les services rendus ou les produits vendus, sauf pour les barbiers-coiffeurs (art. 10).

\section{VII.-Effets du décret:}

Les dispositions du décret sont d'ordre public, c'est-à-dire qu'elles ont préséance sur eelles de toute convention individuelle, de toute convention collective signée en vertu de la Loi des relations ouvrières ou de la Loi des syndicats professionnels, et de toute ordonnance de la Commission du salaire minimum. Elles régissent, dans la juridiction déterminée, tout louage de travail de même nature que celui visé par la convention collective (art. 11).

Il est défendu de stipuler dans un contrat de travail individuel ou une convention collective de travail particulière un salaire différent de celui fixé par le décret (art. 12). Toutefois, les dispositions d'un louage de travail, lorsqu'elles sont à l'avantage du salarié, produisent leur effet, à moins qu'elles ne soient expressément interdites dans le décret (art. 13).

(1) Le premier article de cette série a paru dans le numéro de mars.
L'employeur professionnel qui a habituellement à son emploi des salariés pour un genre de travail affecté par le décret et qui contracte avec un sous-entrepreneur ou sous-traitant, directement ou par intermédiaire, est solidairement responsable avec ce sousentrepreneur ou sous-traitant et tout intermédiaire du paiement du salaire fixé par le décret (art. 14).

N. B. $-A$ noter que l'employeur qui n'a habituellement à son emploi qu'un seul salarié n'est pas regardé comme employeur professionnel au sens de la présente loi.

\section{VIII.-Effets de la publication du décret}

La publication du décret dans la Gazette officielle de Québec rend non recevable toute contestation au sujet de l'incapacité des parties à la convention, de la validité de cette dernière et de l'insuffisance des avis. Et à tous autres égards, elle crée généralement une présomption «juris et de jure» qui établit la légalité de tous les procédés relatifs à son adoption (art. 15).

N. B.-En droit il existe delıx espèces de présomption: la présomption «juris tantum 》 et la présomption «juris et de jure 》,

La présomption «juris tantum » prévaut en l'absence de toute preuve contraire; elle peut donc être refutée. Par contre, la présomption «juris et de jure » ou la présomption invincible ne saurait être repoussée par aucune preuve contraire; elle est décisive.

\section{IX.-Durée du décret:}

Le décret entre en vigueur

a) à compter du jour de sa publication dans la Gazette officielle de Québec ou

b) de la date ultérieure qui y est fixée (art. 7), et

c) a même durée que la convention collective de travail qu'il rend obligatoire. (Voir Loi des relations ouvrières, art. 15).

Par arrêté ministériel dont avis doit toujours être donné dans la Gazette officielle de Québec, le décret peut:

a) ètre prolongé

b) être en tout temps abrogé, et

c) être en tout temps modifié après consultation avec les parties contractantes ou sur requête expresse desdites parties.

La prolongation du décret prend effet à compter du jour de sa ratification.

L'abrogation du décret prend effet à compter du jour de sa publication dans la Gazette officielle de Québec.

La modification du décret prend effet à compter du iour de sa publication dans la Gazette officielle de Québec ou de la date ultérieure qui y est fixée (art. 8).

Marcel FORGET

\section{COLLECTIVE AGREEMENT ACT}

\section{VI.-Provisions of a collective agreement}

which are the object of the Decree:

1.-Essentiel provisions:

The provisions of a collective agreement, whether they are madified or not by the Lieutenant-Governor-in-Council, which become obligatory by the fact of juridical extension and which also bind non-contracting parties as well as contracting parties, are the basic provisions respecting:

a) wages,

b) hours of labor,

c) paid holidays,

d) apprenticeship, and

e) the proportion between the number of skilled workmen and that of apprentices in a given undertaking.

2.-Accessory provisions:

The Lieutenant Governor in Council may also render obligatory with or without modification the provisions of a collective agreement respecting:

a) family allowances,

b) the classification of operations,

c) the determination of the various classes of employees and employers,

(1) The first article of this series has been published in the March issue. d) and such other provisions as the Lieutenant Governor in Council may deem in conformity with the spirit of this Act (Art. 10)

N. B.-It is to be noted that there is no question of fixing in the Decree the prices which are to be charged to the public for services rendered or products sold, except in the case of barbers and hairdressers. (Art. 10).

\section{VII.-Effects of the Decree}

The provisions of the Decree entail a matter of public order, that is to say they have precedence over the provisions of any private agreement, any collective agreement passed in virtue of the Labour Relations Act, any collective agreement passed in virtue of the Professionnal Syndicates Act, and of any ordonnance of the Minimum Wage Commission.

The provisions of a Decree govern within a determined jurisdiction every type of work of the same nature or kind as that contemplated by the collective agreement (Art. 11).

It is forbidden to stipulate in any private contract or in any private collective agreement a wage different from that fixed by the Decree (Art. 12). However, the provisions of a lease and hire of work, when they are more advantageous to the employee, are valid, unless they are expressly forbidden by the Decree (Art. 13).

The professional employer who habitually has in his service employees doing work affected by the Decree and who contracts with a sub-entrepreneur or sub-contractor, directly or through an intermediary, is jointly and severally responsible with such

$$
\text { (Continued on page 8) }
$$

